\title{
Seismic evidence for bottom current activity at the Agulhas Ridge
}

\author{
Etienne Wildeboer Schut*, Gabriele Uenzelmann-Neben, Rainer Gersonde
}

Alfred-Wegener-Institut für Polar-und Meeresforschung, Bremerhaven, Germany

Received 12 August 2000; accepted 11 April 2001

\begin{abstract}
In the South Atlantic water masses from the Atlantic and Indian Oceans meet Antarctic water masses. The Agulhas Ridge, a pronounced elevation of the ocean bottom in the eastern South Atlantic, has acted as a barrier for deep oceanic currents since the Cretaceous, such as the North Atlantic Deep Water (NADW) and Antarctic Bottom Water (AABW), or water masses derived from AABW such as Circumpolar Deep Water (CDW). The history of these currents is recorded in the sedimentary sequence in the adjacent Cape and Agulhas Basins. Seismic profiles over the Agulhas Ridge show sediment packages in the Cape Basin which are interpreted as contourite sheets. These consist of thick sequences interrupted by widespread hiatuses, with a predominantly low seismic reflectivity. The seismic data shows prominent reflectors inside contourite drift bodies which, at the location of the drill-sites of Ocean Drilling Program (ODP) Leg 177, can be attributed to hiatuses in the Early Oligocene, the Middle Miocene, around the Miocene/Pliocene boundary and in the early Pleistocene. In this way, ODP Leg 177 cores were used to date an elongate contourite drift in the Cape Basin. This drift shows sediments deposited by a westward current, implying that the bottom current in the Oligocene followed the same trajectory as present-day CDW does.

(C) 2002 Elsevier Science B.V. All rights reserved.
\end{abstract}

Keywords: South Atlantic; Agulhas Ridge; seismic reflection; palaeo-reconstruction; bottom currents

\section{Introduction}

One of the prime factors controlling regional climate is ocean circulation. The present-day inter ocean exchange of water masses is driven by a global thermo-haline convection system, which transports deep water sediments and partly erodes the ocean bottom. Past ocean circulation can be studied from the effects of deposition and erosion by bottom currents observed in seismic data. This paper focuses on the

\footnotetext{
* Corresponding author.

E-mail address: ewildebr@awi-bremerhaven.de (E. Wildeboer Schut).
}

southern Atlantic, a region where water masses of Atlantic, Indian/Pacific and Antarctic origin meet. Sea-floor spreading and the opening of the South Atlantic Ocean started in the Early Cretaceous (BenAvraham et al., 1993, 1997). The Agulhas Ridge has formed along the Falkland-Agulhas Fracture Zone (FAFZ), a transform fault between the African and South American plates related to the breakup of West Gondwanaland (Ben-Avraham et al., 1997). The Agulhas Ridge represents a pronounced elevation of the sea-floor relative to the adjacent ocean basins, extending from approx. $41^{\circ} \mathrm{S}, 13.5^{\circ} \mathrm{E}$ to $43^{\circ} \mathrm{S}, 9^{\circ} \mathrm{E}$ (Fig. 1) southwest of the coast of South Africa. It separates the Cape Basin north of the ridge from the Agulhas Basin to the south and coincides with the 


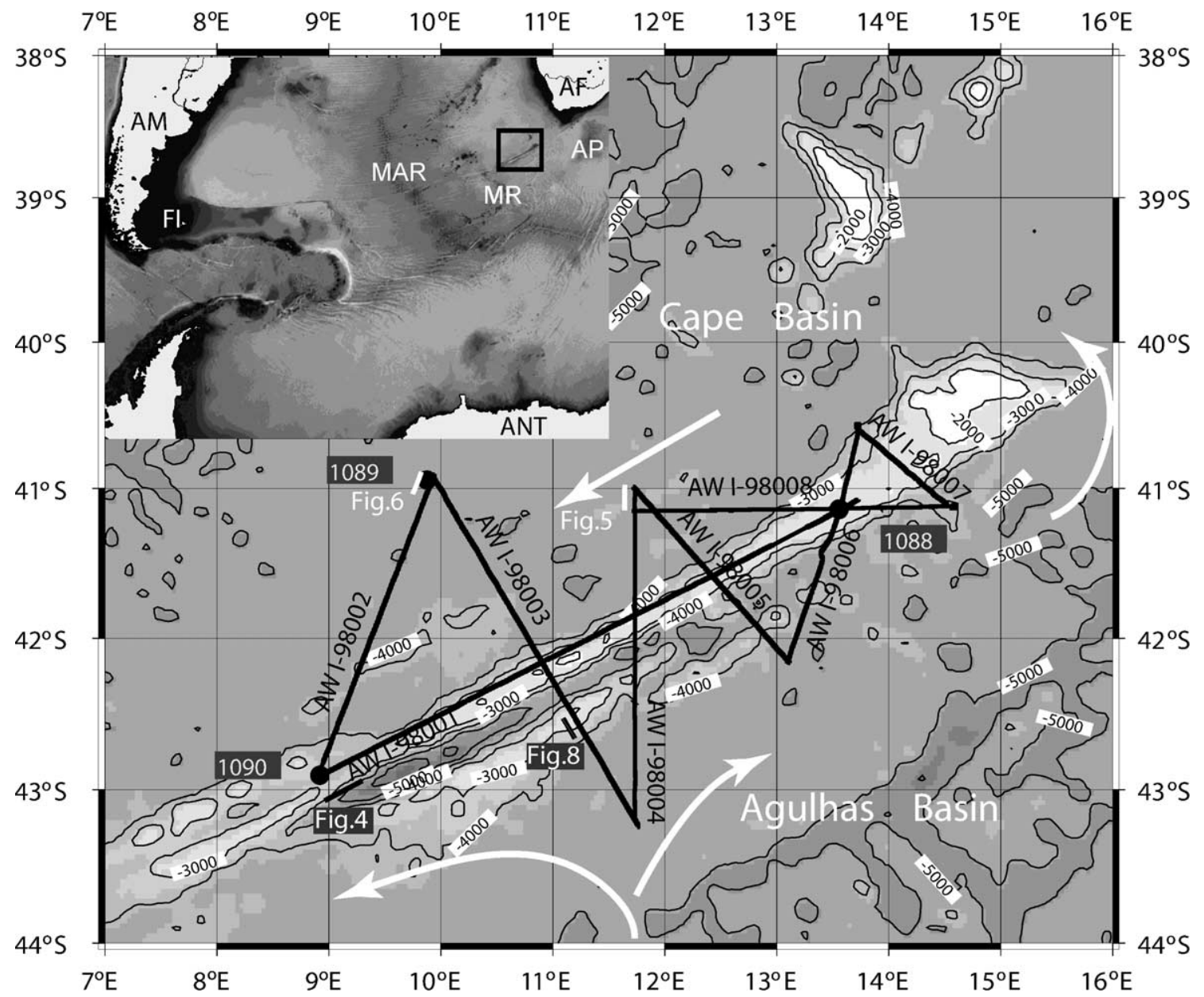

Fig. 1. Bathymetry map of the Agulhas Ridge area after Sandwell and Smith (1997) with seismic profiles AWI-98001 through AWI-98008 and drilling locations of ODP Leg 177 Sites 1088, 1089 and 1089 (big dots); abbr:: AF: Africa, AM: South America, AP: Agulhas Plateau, ANT: Antarctica, FI: Falkland Islands, MAR: Mid Atlantic Ridge; arrows denote flow of the bottom water after Tucholke and Embley (1984).

north of the Meteor Rise at its southwestern end. The northeastern part of the Agulhas Ridge coincides with the location of a spreading centre of the mid-Atlantic ridge south of the FAFZ that was abandoned in the Late Cretaceous (LaBrecque and Hayes, 1979). The age of the Agulhas Ridge makes it a witness to a geological period in which continental drift led to the opening of gateways around the Antarctic and the closure of the Panamanian gateway (Droxler et al., 1998; Lawver and Gahagan, 1998). As a barrier for deep oceanic currents, the Agulhas Ridge had a strong impact on oceanic circulation which is recorded in the sediments near the Agulhas Ridge. Different regions where the sediments originate and the intensity of currents generate particles varying in grain size and fabric. Climatic variations affect relative amounts of calcareous and siliceous sediments through biogenic production influence on carbonate dissolution. The seismic image shows variations in reflectivity of sediments, whether by variation in physical or chemical properties of the sediments, as well as structural features such as drift systems. In this paper, we study past ocean bottom currents from sequence stratigraphic analysis of seismic reflection data at the Agulhas Ridge to monitor changes in deep water flow in the South Atlantic Ocean during the Cenozoic. We 
correlate our seismic data with data from the Ocean Drilling Program (ODP) Leg 177 (Gersonde et al., 1999) for calibration.

\section{Oceanography}

The present general circulation of oceanic currents around the Agulhas Ridge mainly constitutes the North Atlantic Deep Water (NADW), the Circumpolar Deep Water (CDW), and the Agulhas Current coming from the Indian Ocean (Lutjeharms, 1996; Reid, 1996). Near the southernmost tip of the African continent, the Agulhas current dissolves in a ring pattern and mixes with other water masses (Lutjeharms, 1996; De Ruijter et al., 1999). Cold Antarctic Bottom Water (AABW) mixes in the Antarctic Circumpolar Current (ACC) with water masses from the north to form the CDW (Orsi et al., 1999). Northward flowing branches of CDW are deflected in a mainly western direction near the Agulhas Ridge (Tucholke and Embley, 1984; Sykes et al., 1998). A branch enters the Cape Basin along the western coast of South Africa (Fig. 1), from where it flows in a southwestern direction along the ridge until it bends in a northward direction again at the southwestern part of the ridge. This water mass is significantly warmer in the Cape Basin than in other areas with comparable latitude due to mixing and the longer flow path (Tucholke and Embley, 1984). Part of the mixing comes from the NADW which is vertically located between upper and lower CDW (Reid, 1996). Cooling of the northern hemisphere since the Late Pliocene increased the input of NADW at the expense of CDW in the South Atlantic ocean during glaciation cycles (Turneau and Ledbetter, 1989). The shallower Antarctic Intermediate Water originates from surface water around Antarctica. It flows northward into the South Atlantic, extending to depths of approximately $1000 \mathrm{~m}$ around $40^{\circ} \mathrm{S}$ (Turneau and Ledbetter, 1989). In the Cape Basin, it follows an anticyclonic path (Shannon and Hunter, 1988) opposing the direction of underlying CDW. Historically, the onset of the AABW finds its origin in the Oligocene (Mackensen and Ehrmann, 1992; Zachos et al., 1994), during which the opening of the Drake Passage between South America and Antarctica and the separation of Australia and Antarctica took place. This led to the formation of the ACC (Barker and Burrell, 1977; Kennett, 1977; Lawver and Gahagan, 1998) and is responsible for the thermal insulation of Antarctica.

\section{Contourites}

Sediment supply deep in the South Atlantic originates mainly from biogenic production and from deposition by bottom currents (e.g. Tucholke and Embley, 1984). Downslope turbidity currents and along-slope contour currents deposit and erode sediments in the oceanic basins (Faugères and Stow, 1993; Faugères et al., 1999). Contourites are defined as sediment bodies deposited or reworked by the sustained flow of thermo-haline driven geostrophic bottom currents (Heezen et al., 1966; Faugères and Stow, 1993) that are flowing parallel to bathymetric contours in deep sea basins. Such currents are also involved in the exchange of water masses between ocean basins, carrying mainly fine grained sediments due to the generally low current velocity. Deep-sea bottom currents are capable of redistributing sediment bodies over $1000 \mathrm{~km}$ in length (Faugères and Stow, 1993). On the other hand, high velocity bottom currents are also responsible for the creation of large erosional surfaces by scouring the sea-floor. Faugères and Stow (1993) classify contourite drifts in three main morphological types: (a) Giant elongate drifts, parallel to continental margins, or mid-ocean ridge flanks, (b) contourite sheets, sheet like, morphologically flat facies in more or less closed basins, and (c) channel related drifts. Giant elongate drifts have been found to originate in the Oligocene and Early Miocene (Stow et al., 1998). Elongate mounded drifts in seismic sections appear mostly lenticular in shape with a convex geometry and a base that is usually a more or less flat major erosional surface (Faugères et al., 1999). In oceanic basins, the contourite facies are often characterised by an asymmetric levee system due to enhanced deposition on one side and erosion on the other under the influence of the Coriolis force. On the Southern hemisphere, this leads to preferential deposition on the left flank of the channel. This Coriolis effect, interaction between currents and morphology and variation in intensity and interaction with other currents also lead to a prograding lateral migration of the crest (Faugères et al., 1999). Sheet-like 
drift systems often have a discontinuous internal seismic structure, and tend to have low amplitude reflectors, mostly due to the fine and homogeneous sediments (Faugères and Stow, 1993). However, even a small change in supplied sediments, or a variation in current velocity can create erosional surfaces or beds with different seismic reflectivity properties, creating higher amplitude reflectors. Channel-confined drifts have an appearance similar to elongate mounded drifts, with moats along both margins (Faugères et al., 1999). These types of drifts are less commonly observed than the other types. It still is not clear how sea level would influence the occurrence of contourites (Faugères et al., 1999). However, contourites are often observed from periods of climatic instability and sea-level change (Faugères and Stow, 1993). High sea level enhances water mass exchange between the ocean basins, which leads to increased bottom current activity, but also tends to reduce turbidity current activity. On the other hand, bottom current activity is often masked by increased turbidity current activity during low-stands of the sea level (Faugères and Stow, 1993). Antarctic glaciation had an impact on the composition of sediments through alteration in biogenic production rates, as well as variations of the source region and due to flow intensity variations also grain size of supplied terrigenous material. Whether a glaciation favours or diminishes bottom current activity depends on both time scale and origin of the water masses. Although contourite development and glaciation do not seem to be directly linked to each other, there still is an indirect link, as the opening or closing of gateways for ocean water exchange affect both.

\section{Data and methods}

\subsection{Reflection seismic data}

In this paper, we present data from the seismic survey expedition with R/V Petr Kottsov during December 1997 and January 1998 carried out by the Alfred Wegener Institute for Polar and Marine Research (see Uenzelmann-Neben, 1998). Eight profiles of seismic data with a total length of approximately $2000 \mathrm{~km}$ were collected over the Agulhas Ridge extending into the Agulhas and Cape Basins (Fig. 1). An energy source of two GI-guns ${ }^{\mathrm{TM}}$, each with a volume of 45 in. $^{3}$, operating at a pressure of 150 bar were used to obtain 96 channel records with $25 \mathrm{~m}$ spacing between the channels and a recorded length of $8 \mathrm{~s}, 1 \mathrm{~ms}$ sample-interval. The bandwidth of the data was around $150 \mathrm{~Hz}$, with a maximum frequency of $75 \mathrm{~Hz}$. Special care for noise reduction was necessary due to extreme weather conditions during acquisition. The data were sorted in CMPs with a distance of $25 \mathrm{~m}$ between the consecutive locations. Noisy traces have been removed and the data were filtered for noise reduction prior to velocity analysis. Stacked seismic sections were created after normal moveout correction and additional coherency filtering for further noise reduction. These sections were time-migrated to enhance the resolution of geological structures in the subsurface.

\subsection{ODP Leg 177 data}

The seismic profiles connect three ODP sites drilled during Leg 177 with R/V Joides Resolution between December 1997 and February 1998 (Gersonde et al., 1999). Sites 1088 and 1090 were drilled at the Agulhas Ridge while Site 1089 is located in the adjacent Cape Basin (Fig. 1). Middle Miocene to Holocene sediments have been recovered. The core samples were studied with respect to sedimentological, physical and chemical properties and preliminary age models have been established based on combined magneto- and biostratigraphic methods (Gersonde et al., 1999).

Site 1088, at $2092 \mathrm{~m}$ depth on top of the Agulhas Ridge, consists mainly of calcareous sediments (Shipboard Scientific Party, 1999a), with carbonate percentages varying from 85 to 95 wt.\% (Fig. 2). In total, $233.7 \mathrm{~m}$ of Holocene to Middle Miocene sediments were cored with the objective to recover a long Cenozoic carbonate sequence to study palaeoceanographic changes near the Sub-tropical Front (Shipboard Scientific Party, 1999a). Due to technical problems, it was not possible to drill sediments of early Cenozoic age. Two hiatuses were found, in the Middle Miocene and between Pliocene and Pleistocene.

At Site 1089, in the southernmost Cape Basin (Fig. 1), a sedimentary sequence of $264.9 \mathrm{~m}$ at a water depth of $4620 \mathrm{~m}$ was obtained, which documents the Holocene to the Late Pliocene (2.4 Ma) (Fig. 2). The Pleistocene section has been deposited at high sedi- 


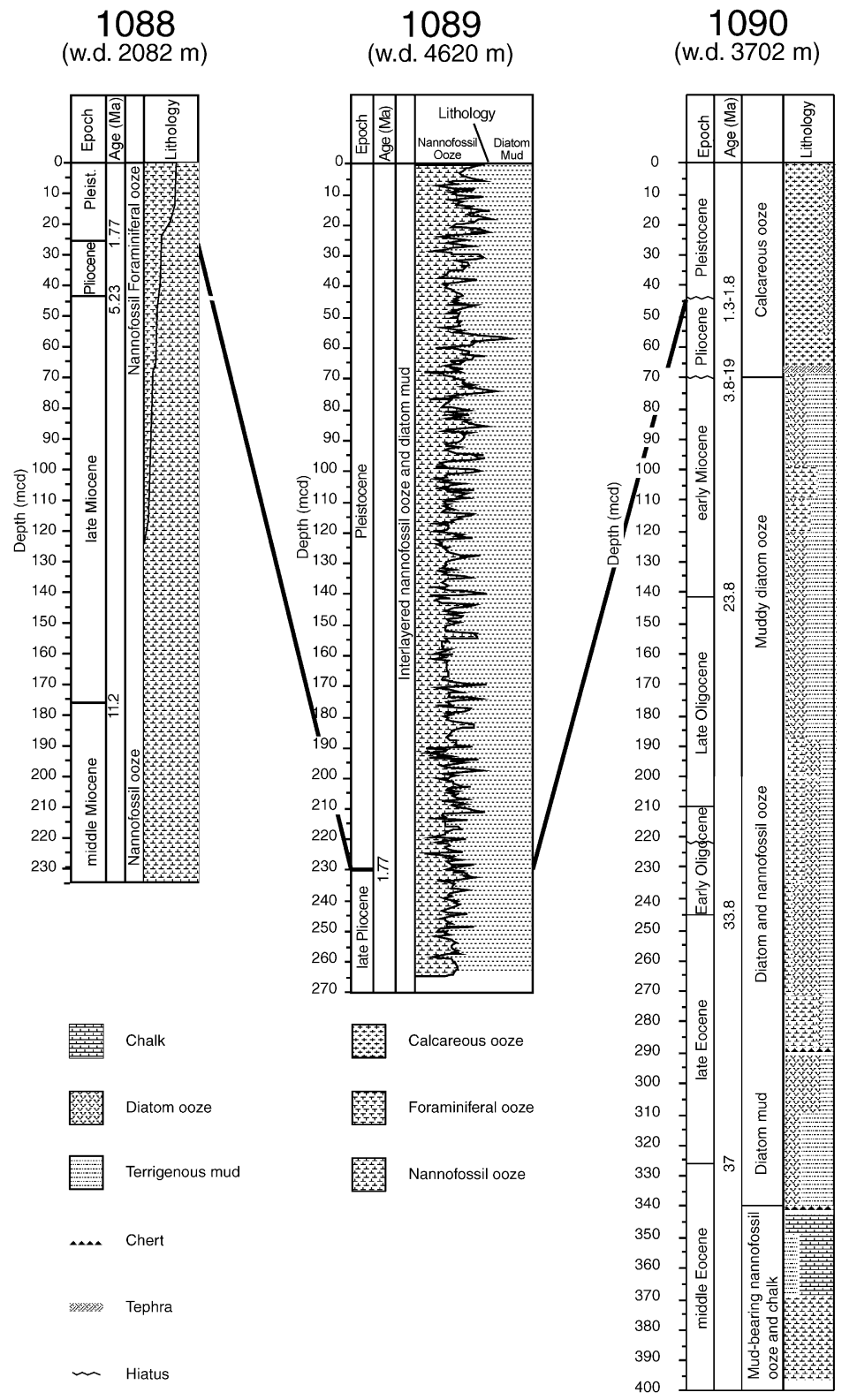

Fig. 2. Summary of lithologies for ODP Leg 177 Sites 1088, 1089 and 1090 after Gersonde et al. (1999) and Shipboard Scientific Party $(1999 \mathrm{a}, \mathrm{b}, \mathrm{c}) . \mathrm{wd}=$ Water depth, $\mathrm{mcd}=$ meters composite depth.

mentation rates (ca. $130-140 \mathrm{~m} / \mathrm{Ma}$ ), while Pliocene sedimentation rates decline to $\sim 40 \mathrm{~m} / \mathrm{Ma}$ (Zielinski and Gersonde, in press). Core samples between 95 and 156 meters composite depth (mcd) (Shipboard Scientific Party, 1999b) show that the sediments are slightly slumped. However, the sedimentary sequence remains stratigraphically continuous (Zielinski and Gersonde, in press). This provides records of Pleistocene glaciation cycles with high temporal resolution. The sediments have a fluctuating carbonate content between 0 and 60 wt.\% due to variation in the amounts of terrigenous mud and changes in car- 
bonate preservation. The Pliocene/Pleistocene boundary is well defined in Site 1089 and is located at ca. $230 \mathrm{mcd}$ (Zielinski and Gersonde, in press).

Site 1090, at the southern end of the Agulhas Ridge, was placed at a water depth of $3702 \mathrm{~m}$. Due to one or two disconformities between 71.5 and 78.5 mcd, which separate lower Pliocene and probably uppermost Miocene sediments from lower Miocene sequences, drilling at Site 1090 reached the Middle Eocene at 397 meters below sea floor (mbsf) (Shipboard Scientific Party, 1999c). While the study of planktic foraminifers by Galeotti et al. (submitted for publication) indicates two disconformities at 71.5 and $78.5 \mathrm{mcd}$, separating Early Pliocene from Late Miocene and Late Miocene from Early Miocene, respectively, shipboard stratigraphic data also including the geomagnetic inclination record reveal one disconformity at around $70 \mathrm{mcd}$ which separates the Early Pliocene from the Early Miocene and spans ca. 14 Ma (Shipboard Scientific Party, 1999c). Increased bottom-current velocity caused widespread hiatuses in oceanic sediments in many other areas as well (e.g. Ledbetter and Ciesielski, 1982; Keller, 1987). The study of planktic foraminifers also indicates strong reworking of late Cretaceous (Campanian-Maastrichtian to Miocene) planktic foraminifers at around 71.5 mcd (Galeotti et al., submitted for publication). Three other short-ranging disconformities have been encountered in the Pleistocene (Venz and Hodell, in press), two being close to the Plio/Pleistocene boundary at around $40-43 \mathrm{mcd}$. Calcareous nannofossil investigations point to a hiatus at around $220 \mathrm{mcd}$, in the Early Oligocene, which spans about $3 \mathrm{Ma}$ (Marino and Flores, submitted for publication). Nannofossils, diatoms and mud comprise the major lithologic components of the sediments recovered at Site 1090. While the Middle and early Late Eocene consist of mud-bearing nannofossil ooze and chalk, the Late Eocene to Early Miocene is characterised by mudbearing diatom ooze and diatom bearing nannofossil ooze and chalk. The Plio/Pleistocene sequences are characterised by alternations of nannofossil ooze and

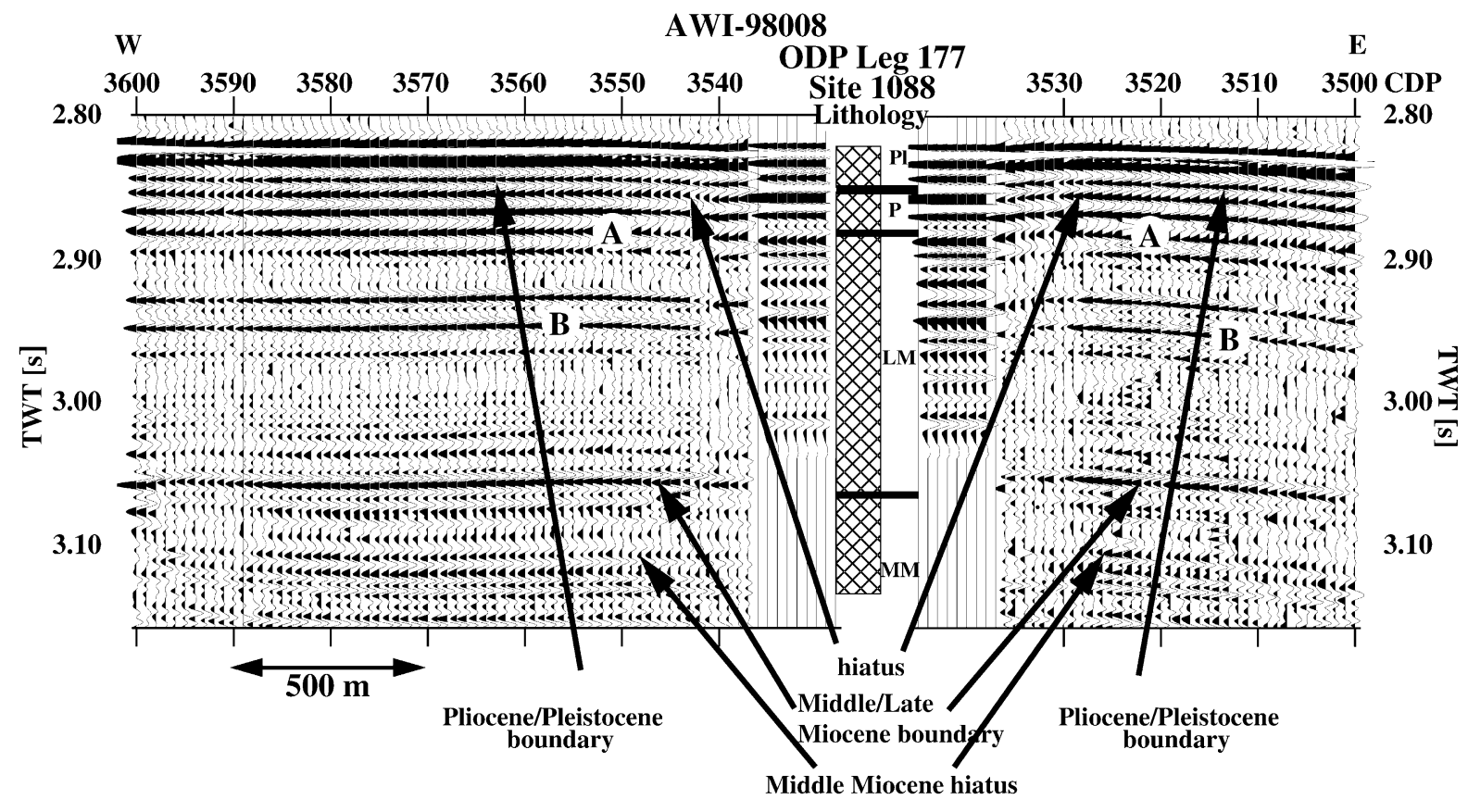

Fig. 3. Lithology and synthetic seismograms derived from ODP Leg 177 Site 1088 core data (after: Shipboard Scientific Party, 1999a), on the northern segment of the Agulhas Ridge (see Fig. 1). The lithology is predominantly calcareous. Placements of lithologic boundaries are based on fossil analysis. The seismic reflectors of profile AWI-98008 show good correlation with these boundaries as well as with the synthetic data. 


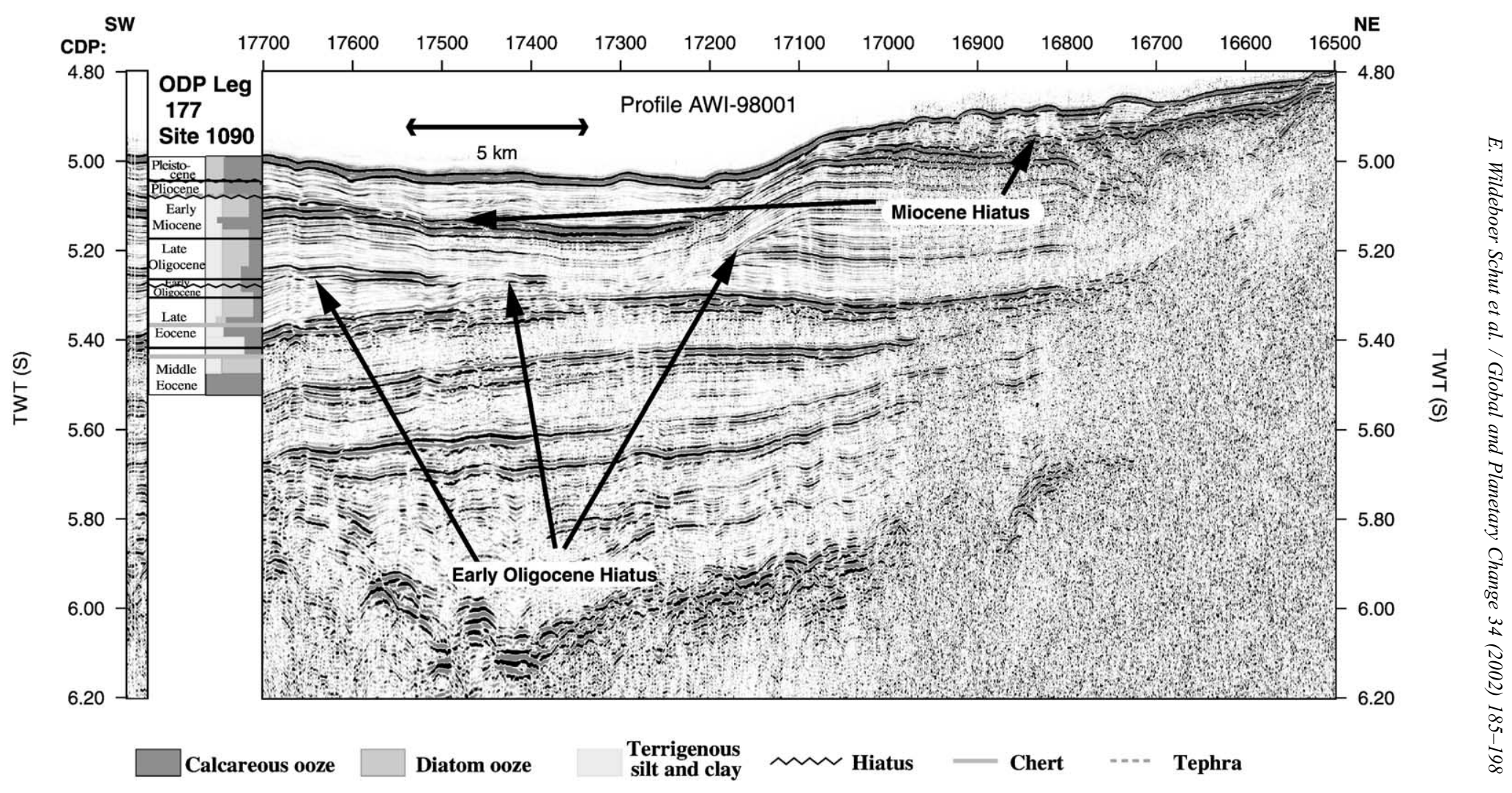

Fig. 4. Lithology of ODP Leg 177 Site 1090 (Shipboard Scientific Party, 1999c) on the southwestern side of the Agulhas Ridge correlated with seismic data. An Early Oligocene hiatus can be traced in the Cape Basin as well, shown in Figs. 5 and 6 as reflector O. Reflector M in these figures corresponds to the Miocene hiatus found in Site 1090 cores. 
diatom-bearing nannofossil ooze. A chert layer has been encountered at 290 and $340 \mathrm{mbsf}$, respectively, in the Eocene section (Shipboard Scientific Party, 1999c). The disconformity at around $70 \mathrm{mcd}$ is underlain by a tephra layer (Shipboard Scientific Party, 1999c).

\subsection{Incorporation of geological and seismic data}

The physical properties measured on the recovered sediments include density and seismic P-wave velocity (Gersonde et al., 1999). From these data, synthetic seismic data were constructed at the core locations, which can be compared with the recorded seismic data. In this way, age control of the seismic data is possible, as the synthetic data is based on the same core samples as is used for age dating by the analysis of fossils in the sediments. Erosional surfaces found in core samples, as well as changes in depositional conditions as inferred from core data, can be linked with reflection seismic horizons. Both chemical and physical properties of sediments have an impact on the density and P-wave velocity, and thus influence the reflectivity of seismic horizons.

Density and P-wave velocity are available for all three sites (Shipboard Scientific Party, 1999a,b,c). After removal of spurious data, correlation between various holes and interpolation to fill in depth ranges with missing data, it was possible to construct a series of seismic impedances, and with these, a reflectivity sequence. The P-wave velocities were used to convert the data from depth-domain into time-domain and after convolution with a $75-\mathrm{Hz}$ Ricker wavelet synthetic seismograms were generated.

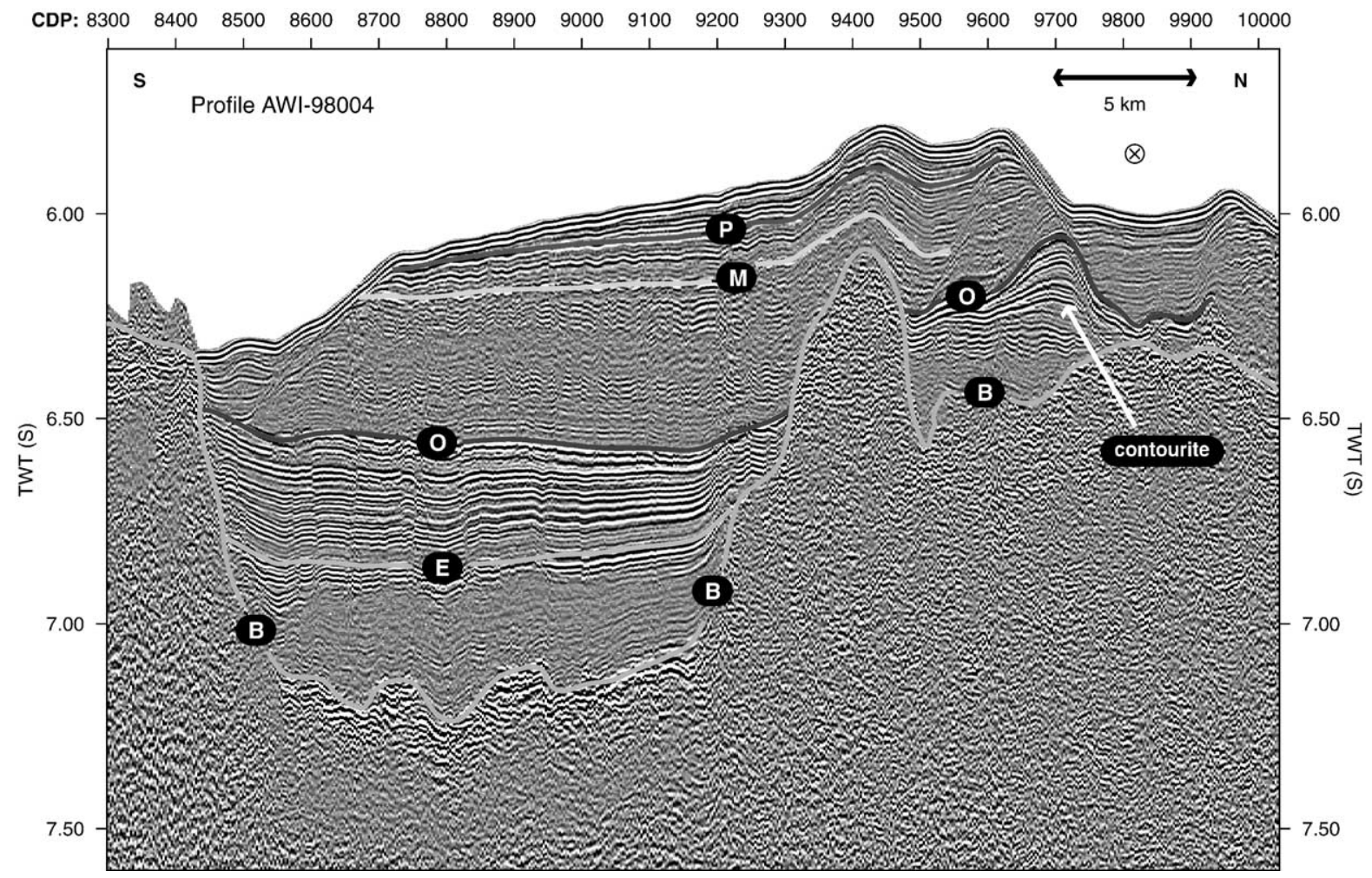

Fig. 5. Part of seismic profile AWI-98004 in the Cape Basin showing a contourite deposit. The $\otimes$ symbol denotes flow direction in westward direction of the palaeo bottom current, responsible for deposition of the contourite. Reflector E corresponds to the top of a pre-Oligocene sedimentary sequence, probably Late Eocene, reflector O marks an Early Oligocene erosional surface, reflector M corresponds to a Miocene hiatus, reflector $\mathrm{P}$ denotes base Pleistocene. B denotes top basement. 


\subsection{Results}

On the basis of constructed synthetic seismograms, we identified the seismic reflectors on profile AWI98008, at the location of Site 1088, corresponding with hiatuses like at the Pliocene/Pleistocene boundary (Shipboard Scientific Party, 1999a) and a hiatus at 209 mcd (Marino and Flores, submitted for publication) in the Middle Miocene. Also, increased sediment rates often accompany lithologic variations, creating reflectors, like at the Miocene/Pliocene boundary (denoted A in Fig. 3), where sedimentation increases from 7.5 . to $17 \mathrm{~m} / \mathrm{Ma}$, and in the Late Miocene (denoted B) where sedimentation increases from 17 to $30 \mathrm{~m} / \mathrm{Ma}$ (Shipboard Scientific Party, 1999a).

Fig. 4 shows that the Miocene hiatus as cored at Site 1090 and the Early Oligocene hiatus are related to distinct seismic reflectors as well. A comparison of the stratigraphic sequence in the seismic data at CDP 17000 of profile AWI-98001 (Fig. 4) and CDP 17700 near the location of Site 1090 shows that a sequence of approximately $80 \mathrm{~m}$ of sediments is missing at the Early Oligocene hiatus at Site 1090. Considering a duration of $3 \mathrm{Ma}$ of the Early Oligocene hiatus at Site 1090 (Marino and Flores), this would suggest sedimentation rates of $25-30 \mathrm{~m} / \mathrm{Ma}$ during the Early Oligocene. These reflectors can be identified on several profiles in the Cape Basin, for instance profile AWI-98004 (Fig. 5) and profile AWI-98002 (Fig. 6), where the Early Oligocene and the Miocene hiatus are denoted as reflectors $\mathrm{O}$ and $\mathrm{M}$, respectively. The sequence between $\mathrm{O}$ and $\mathrm{M}$ can be identified not only based on these strong reflectors and clear unconformities, like for the Early Oligocene hiatus on profile AWI-98001, but also by the transparent seismic character of the sediments in between these reflectors. This is attributed to the moderate sedimentation rates of $10-20 \mathrm{~m} / \mathrm{Ma}$ without drastic change in the depositional facies (Diekmann et al., submitted for publication) and a relatively high concentration of siliceous sediments (Diekmann et al., submitted for publication). Several hundred meters of sediment have accumulated in a buried drift where a mound has been built up in the CMP range 9450-9850 (Fig. 5). The strong reflector over this drift structure, just before a westward migration of the crest, can be related to the Early Oligocene hiatus recovered at Site 1090 (Fig. 4).

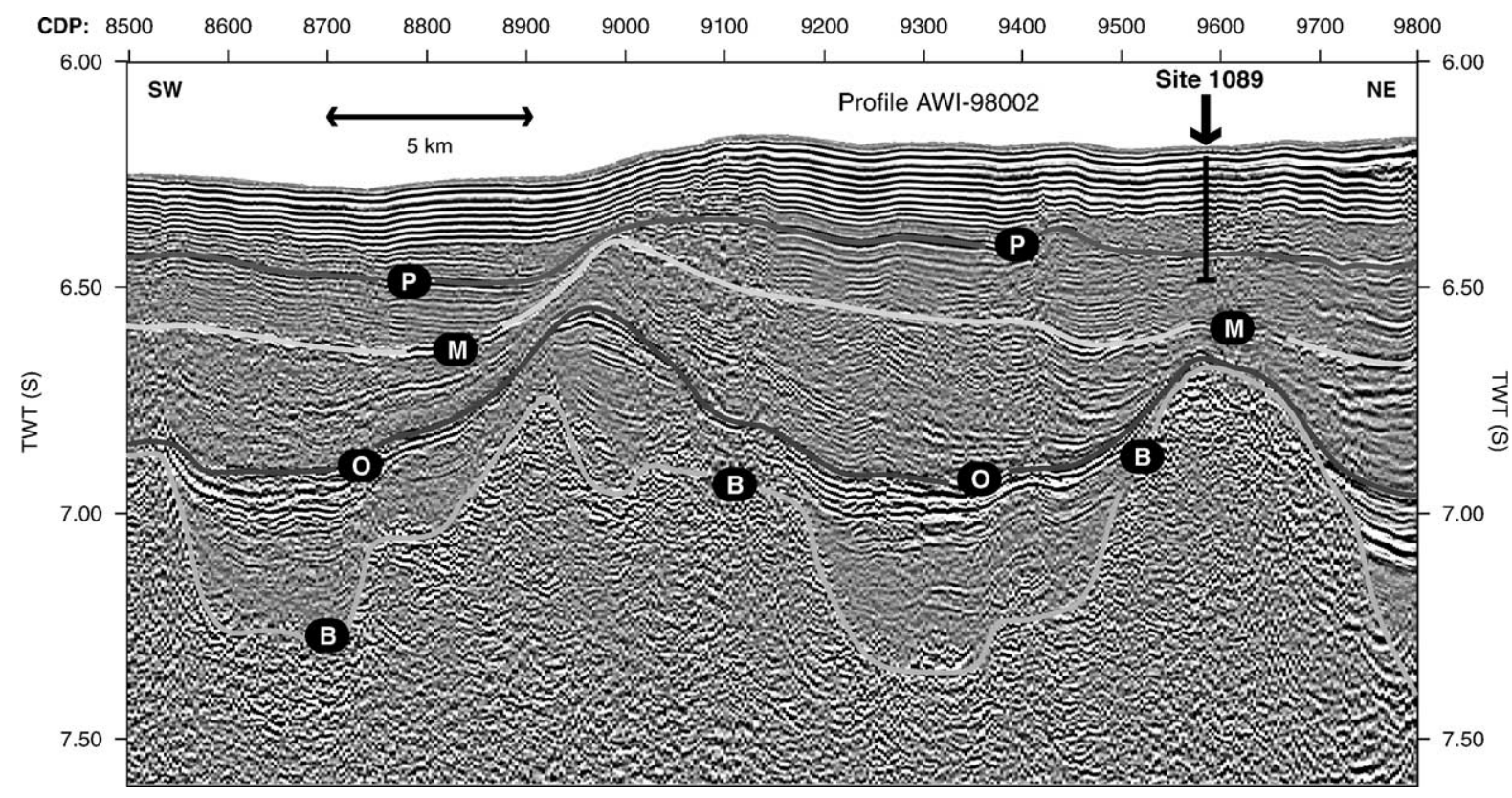

Fig. 6. Part of seismic profile AWI-98002 with bottom current deposits. The reflector O denotes an Early Oligocene erosional surface, reflector $\mathrm{M}$ corresponds to a Miocene hiatus and reflector P corresponds to base Pleistocene. B denotes top basement. 


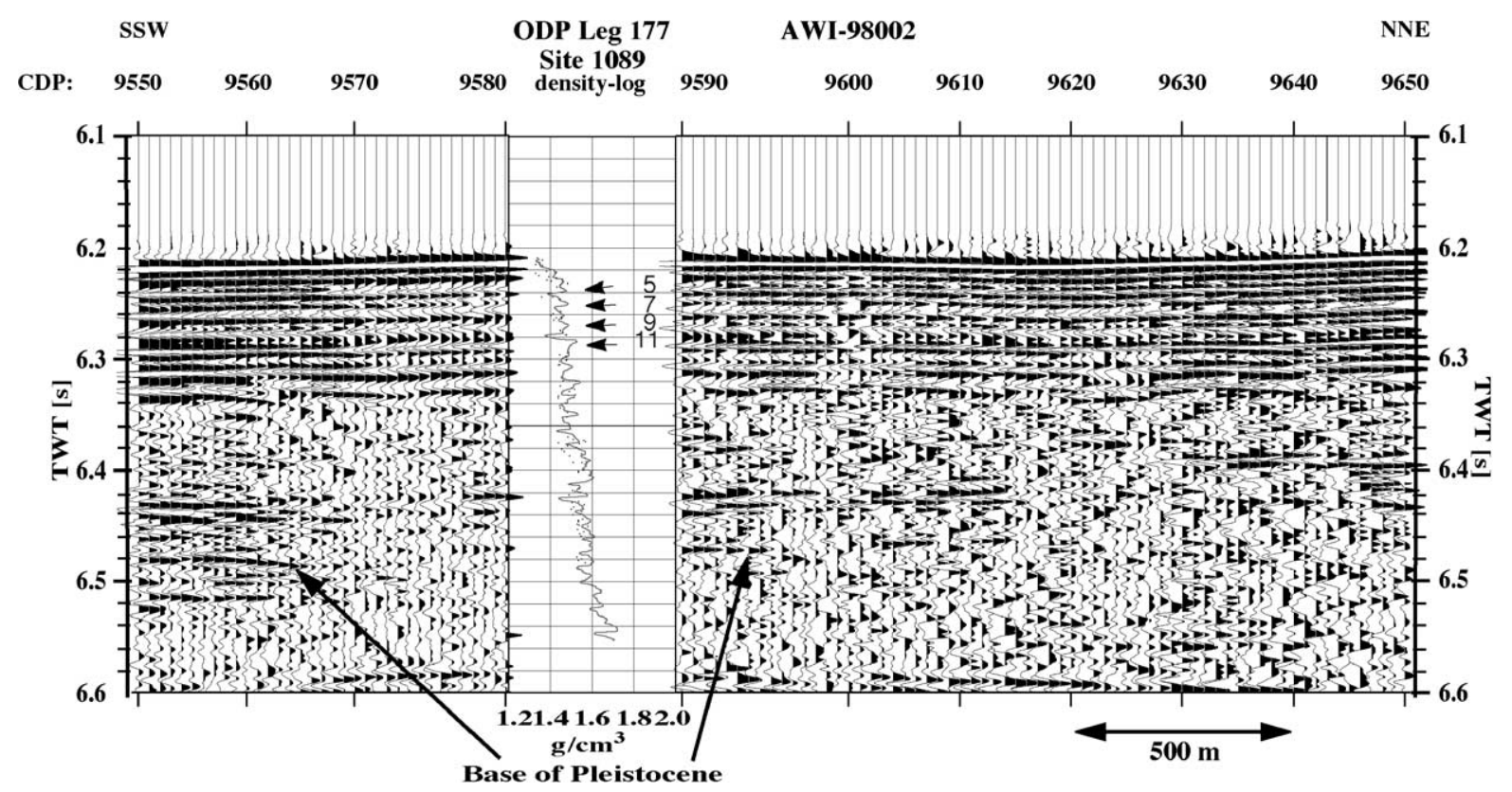

Fig. 7. Densities derived from gamma ray porosity measurements (solid line) and direct measurements at selected core samples for ODP Leg 177 Site 1089 (Shipboard Scientific Party, 1999b), situated in the Cape Basin (see Fig. 1) correlated with seismic data. The base of the Pleistocene derived from fossil analysis is visible as a reflector in the seismic data (profile AWI-98002) and is denoted as reflector P in Figs. 5 and 6. The numbers indicate various oxygen marine isotope stages, age after Imbrie et al. (1984).

The drilling at Site 1089 identified the location of the base of the Pleistocene, denoted as horizon $\mathrm{P}$ (Figs. 5 and 6). During the Pliocene, of which sequences are located between reflectors $\mathrm{M}$ and $\mathrm{P}$, an increase in well-defined reflectors is observed. This holds even more for the Quaternary sediments, above reflector P. This increase in well-defined seismic reflectors can be explained by the increase of the glaciation cycle frequency, responsible for sea-level variation and variations in sediment supply. This is clearly illustrated in Fig. 7, which shows that the density of the sediments correlates with seismic reflectors and that the seismic reflectors occur with a periodicity that correlates with marine isotope stages in Pleistocene times (Imbrie et al., 1984).

\section{Discussion}

The seismic profiles in the vicinity of the Agulhas Ridge show that the Agulhas Ridge has two ridge segments, separated by a $20-\mathrm{km}$-wide moat, filled with sediments and a bathymetric relief of up to 3 $\mathrm{km}$ relative to the adjacent basins. The ridge itself is largely of magmatic origin (Hartnady and le Roex, 1985; Kastens, 1987) and although near Site 1088 and 1090 there is a thick sedimentary sequence, it generally shows little sedimentary cover. By contrast, the Cape and Agulhas Basins show thick layers of sediments on top of the magmatic basement of the oceanic crust. The seismic data shows extensive occurrence of intrusions which affect Cenozoic sediments. This suggests that development of the Agulhas Ridge still continued after the spreading axis at its eastern boundary was abandoned in the Late Cretaceous (LaBrecque and Hayes, 1979). The thick sediment layers in the oceanic basins are interpreted as contourite sheets consisting of fine grained, bioturbated and homogeneous sediments. This is illustrated by the sediments in Figs. 5 and 6, between reflectors O, an Early Oligocene hiatus and $\mathrm{M}$, a hiatus between Miocene and Pliocene. Widespread discontinuities, marked by a continuous prominent reflector are a characteristic property of contourites (Faugères et al., 1999). Discontinuities in contourite facies are the result of a period of erosion or non-deposition due to intensified 
current activity or by a compositional change (Faugères et al., 1999). The sediments encountered on profiles AWI-98004 (Fig. 5) and AWI-98002 (Fig. 6) are seismically relatively transparent, i.e. they show mainly low amplitude seismic reflections. This is indicative of a contouritic sheet that has been built up by a steady bottom current with little variations in sediment supply. Reflectors in intermittent reflective sequences are highly discontinuous, a result of bioturbation and differential compaction.

An expression of bottom currents forced to follow the Agulhas Ridge is observed in this sediment sequence at the northern end of profile AWI-98004 in the Cape Basin (Fig. 5). The transect of this drift is up to $7.5 \mathrm{~km}$ in a direction perpendicular to the Agulhas Ridge, with the crest migrating towards the Agulhas Ridge for younger sediments. The reflectors below the Oligocene hiatus within this elongate contourite drift (Fig. 5, CMP 9450-9850) are more pronounced than younger sediments. The explanation for this variation in reflectivity lies within changes in depositional environment, for instance relative changes in current velocities, as a higher velocity environment leads to coarser grain-sized sediments. Another possibility is a compositional change of the sediments, e.g. by an increase or decrease of siliceous components. Indeed, the lithology of Site 1090 (Fig. 2) shows a change towards more terrigenous material in sediments younger than Early Oligocene. An asymmetric signature of deposition and migration of the crest towards the left side of the current (on the southern hemisphere) is characteristic for elongate contouritic drifts due to the Coriolis effect and suggests a westward bottom current. This drift is also apparent on profile AWI-98008 as a very wide sequence of sediment layers as this profile is mostly parallel to the drift. The Agulhas Ridge has clearly acted as a barrier for sediment carrying ocean currents, forcing the current to flow parallel to the ridge. The present-day bottom current in this part of the Cape Basin also follows a westward path (Tucholke and Embley, 1984; Faugères et al., 1993). From this observation we deduce that since the Early Oligocene a bottom water current comparable to the present-day bottom current sweeps the Cape Basin and follows the same trajectory. Previously, Johnson (1985) found a rapidly accumulating bottom current deposits beginning in the Early Oligocene due to AABW flow in the western South Atlantic. This suggests that bottom current activity occurred already on a large scale in the Oligocene.

In the Agulhas Basin bottom current activity can be observed as well. Here, the bottom current direction is more ambiguous, as the main branch of ACC in the Agulhas Basin follows a westward path (Tucholke and Embley, 1984), but part of it is deflected in an eastward direction and flows counter-clockwise around the Agulhas Ridge. A result of this eastward branch is present in section AWI-98003, just south of the Agulhas Ridge (Fig. 8), where a small elongate contourite drift can be observed between CMP 9050 and 9150 . The scale of this contourite is of much lesser extent than the drift on profile AWI-98004 in the Cape Basin (Fig. 5), due to the more pronounced basement topography in the Agulhas Basin which confines the drift on profile AWI-98003. The location of this drift limits its vertical scale since the location on the flank of the Agulhas Ridge prohibits the development of thick sediment packages and for this reason it is not possible to attach a known time scale from any of the ODP drill sites to the drift. The mound has a lateral extent of less than $2 \mathrm{~km}$, overlain by sediments at $5.5 \mathrm{~s}$ TWT, probably originating at the top of the Agulhas Ridge and resedimented by downslope currents. Giant sheets of bottom current sediments are not observed in the Agulhas Basin as the topography is much rougher than it is in the Cape Basin. Material from the ridge, eroded by shallow currents, can be a source of the sediments in the form of turbidites, to be redeposited by bottom currents in the basins. Possible sources for erosion could be intermediate water masses or perhaps interaction with Agulhas Rings. As most recent oceanfloor spreading in the area of the Agulhas Ridge took place near the location of Site 1088, it is this part of the ridge which has the shallowest sea-floor. Closest to the African continent, this is also the location where possible interaction with rings shedded from the Agulhas Retroflection would be strongest. This effect should be one of supply of sediments, as in contrast to most of the Agulhas Ridge, Site 1088 shows a thick sediment cover for which core analysis shows that accumulation rates at Site 1088 are relatively high (Shipboard Scientific Party, 1999a). If this is the case, relatively high input of terrigenous particles from the African continent could be expected. The high carbonate content of 85 to 95 wt.\% (Shipboard Scientific 


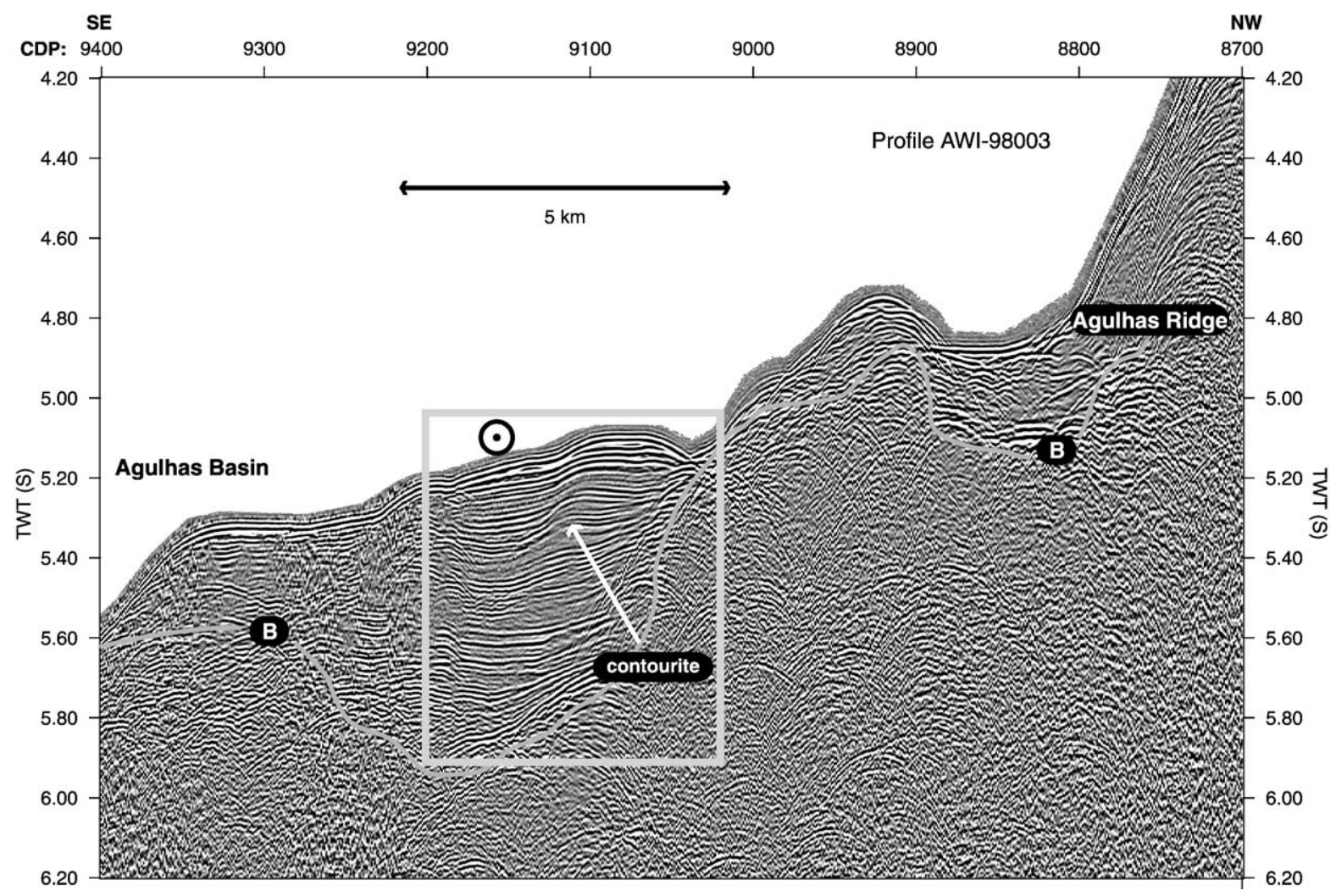

Fig. 8. Profile AWI-98003 just south of the Agulhas Ridge. The outlined area shows a buried contourite drift, probably overlying a sequence of turbidites. The asymmetric appearance of the horizons suggests a current direction oblique to the profile in eastern direction (denoted by symbol $\odot)$. B denotes top basement.

Party, 1999a) suggests that deposition of sediments transported by Agulhas Rings does not play a big role on the Agulhas Ridge itself. Deeper in the Cape Basin where very high sedimentation rates are found, with a high content of terrigenous components the situation may be different.

\section{Conclusions}

Opening and closing of critical gateways for interocean water exchange at the Eocene-Oligocene boundary contributed to the development of currents like the ACC and Circumpolar Deep Water, a mixture of $\mathrm{AABW}$ and water masses from the Atlantic, Indian and Pacific oceans. The effects of early bottom water currents can be found in the oceanic basins adjacent to the Agulhas Ridge, which already existed at the onset of AABW development. Our seismic data show bottom current activity, documented by contourite deposits, already in the Oligocene. A southwestward bottom current was inferred for the Cape Basin, along the northern slope of the Agulhas ridge. South of the Agulhas Ridge, a small contourite drift in the Agulhas Basin indicates an eastward flow of bottom water during deposition. It is not clear if this flow can be attributed to a branch of bottom water with an Antarctic origin, and neither can its age be determined, but like the Oligocene bottom current in the Cape Basin, it has the same direction as the present-day bottom current circulation as shown by Tucholke and Embley (1984). Widespread hiatuses formed in the Early Oligocene and in the Miocene, related to periods of erosion or non-deposition, and rapidly increased sedimentation, near the Pliocene/Pleistocene boundary and in the Miocene, lead to abrupt lithologic variations. 
Such variations appear as outstanding reflectors in the otherwise low reflective seismic sequences as found throughout the Cape Basin. Variations in current activity, resulting in increased or decreased supply of sediments and intensity of current velocity are also responsible for the characteristics of the seismic reflections. Sediments of Early Oligocene origin as well as Quaternary sediments show clear seismic reflectors, whereas sediments between the Early Oligocene and the Miocene hiatus are seismically transparent with few, discontinuous reflectors. This transparent package corresponds with an increase in the relative amount of terrigenous mud in the sediments, during a period in which deposition took place at moderate sedimentation rates. This indicates constant, low velocity, currents and hence small grain size sediments during Late Oligocene and Miocene. For Pleistocene sequences, the climate instability resulted in rapid variation in sediment supply which leads to pronounced seismic reflectors.

\section{Acknowledgements}

We are grateful for the support of the captain and crew of R/V Petr Kottsov for their help during the expedition. We also want to thank Bernhard Diekmann for his comments and review of the draft paper. The expedition was funded by the German Bundesministerium für Bildung, Forschung und Technologie under contract No. 03G0532A. This research was funded by the Deutsche Forschungsgemeinschaft. We also want to thank the reviewers for their valuable comments. This is AWI contribution number awi-n10080.

\section{References}

Barker, P.F., Burrell, J., 1977. The opening of Drake Passage. Mar. Geol. 25, 15-34.

Ben-Avraham, Z., Hartnady, C.J.H., Malan, J.A., 1993. Early tectonic extension between the Agulhas Bank and the Falkland Plateau due to the rotation of the Lafonia microplate. Earth Planet. Sci. Lett. 117, 43-58.

Ben-Avraham, Z., Hartnady, C.J.H., Kitchin, K.A., 1997. Structure and tectonics of the Agulhas-Falkland fracture zone. Tectonophysics 282, 83-98.

De Ruijter, W.P.M., Biastoch, A., Drijfhout, S., Lutjeharms, J.R.E., Matano, R.P., Pichevin, T., Van Leeuwen, P.J., Weijer, W., 1999.
Indian-Atlantic inter-ocean exchange: dynamics, estimation and impact. J. Geophys. Res., C 104, 20885-20910.

Diekmann, B., Kuhn, G., Gersonde, R., et al., submitted for publication. Middle Eocene to Early Miocene sediment record of long long-term climate change and environmental implications of a late eocene opal event in the pelagic SE Atlantic sector of the Southern Ocean (ODP Site 1090).

Droxler, A.W., Burke, K.C., Cunningham, A.D., Hine, A.C., Rosencrantz, E., Duncan, D.S., Hallock, P., Robinson, E., 1998. Caribbean constraints on circulation between Atlantic and Pacific Oceans over the past 40 million years. In: Crowley, T.J., Burke, K.C. (Eds.), Tectonic Boundary Conditions For Climate Reconstruction, Oxford Monographs on Geology and Geophysics, vol. 39. Oxford Univ. Press, New York, pp. 169-191, Chap. 8.

Faugères, J.C., Stow, D.A.V., 1993. Bottom-current-controlled sedimentation: a synthesis of the contourite problem. Sediment. Geol. 82, 287-297.

Faugères, J.C., Mézerais, M.L., Stow, D.A.V., 1993. Contourite drift types and their distribution in the North and South Atlantic Ocean basins. Sediment. Geol. 82, 189-203.

Faugères, J.C., Stow, D.A.V., Imbert, P., Viana, A., 1999. Seismic features diagnostic of contourite drifts. Mar. Geol. 162, 1-38.

Galeotti, S., et al., submitted for publication.

Gersonde, R., Hodell, D.A., Blum, P., et al. (Eds.), 1999. Proceedings of the Ocean Drilling Program, Initial Reports, vol. 177 [CD-ROM]. Available From: Ocean Drilling Program. Texas A\&M University, College Station, TX 77845-9547, USA.

Hartnady, C.J.H., le Roex, A.P., 1985. Southern ocean hotspot tracks and the Cenozoic absolute motion of the African, Antarctic and South American plates. Earth Planet. Sci. Lett. 75, 245-257.

Heezen, B.C., Hollister, C.D., Ruddiman, W.F., 1966. Shaping of the continental rise by deep geostrophic contour currents. Science $152,502-508$.

Imbrie, J., Hays, J.D., Martinson, D.G., McIntyre, A., Mix, A.C., Morley, J.J., Pisias, N.G., Prell, W.L., Shackleton, N.J., 1984. The orbital theory of Pleistocene climate: support from a revised chronology of the marine $\delta^{18} \mathrm{O}$ record. In: Berger, A., Imbrie, J., Hays, J., Kukla, G., Saltzman, B. (Eds.), Milankovitch and Climate. Reidel, Dordrecht, pp. 269-305.

Johnson, D.A., 1985. Abyssal teleconnections: II. Initiation of Antarctic Bottom Water flow in the southwestern Atlantic. In: Hsü, K.J., Weissert, H.J. (Eds.), South Atlantic Paleoceanography. Cambridge Univ. Press, Cambridge, pp. 243-281, Chap. 14.

Kastens, K.A., 1987. A compendium of causes and effects of processes at transform faults and fracture zones. Rev. Geophys. 25, 1554-1562.

Keller, G., 1987. Paleodepth distribution of Neogene deep-sea hiatuses. Paleoceanography 2, 697-713.

Kennett, J.P., 1977. Cenozoic evolution of Antarctic glaciation, the circum-Antarctic ocean, and their impact on global paleoceanography. J. Geophys. Res. 82, 3843-3860.

LaBrecque, J.L., Hayes, D.E., 1979. Seafloor spreading history of the Agulhas Basin. Earth Planet. Sci. Lett. 45, 411-428.

Lawver, L.A., Gahagan, L.M., 1998. Opening of Drake Passage and its impact on Cenozoic ocean circulation. In: Crowley, T.J., Burke, K.C. (Eds.), Tectonic Boundary Conditions for Climate 
Reconstruction, Oxford Monographs on Geology and Geophysics, vol. 39. Oxford Univ. Press, Oxford, pp. 212-223, Chap. 10.

Ledbetter, M.T., Ciesielski, P.F., 1982. Bottom-current erosion along a traverse in the south Atlantic sector of the Southern Ocean. Mar. Geol. 46, 329-341.

Lutjeharms, J.R.E., 1996. The exchange of water between the South Indian and the South Atlantic oceans. In: Wefer, G., Berber, W.H., Siedler, G., Webb, D.J. (Eds.), The South Atlantic: Present and Past Circulation. Springer-Verlag, Berlin, pp. 125-162.

Mackensen, A., Ehrmann, W.U., 1992. Middle Eocene through Early Oligocene climate history and palaeoceanography in the Southern Ocean: stable oxygen and carbon isotopes from ODP sites on Maud Rise and Kerguelen Plateau. Mar. Geol. 108, $1-27$.

Marino, M., Flores, J.A., submitted for publication.

Orsi, A.H., Johnson, G.C., Bullister, J.L., 1999. Circulation, mixing and production of Antarctic Bottom Water. Progr. Oceanogr. 43, $55-109$.

Reid, J.R., 1996. On the circulation of the South Atlantic Ocean. In: Wefer, G., Berber, W.H., Siedler, G., Webb, D.J. (Eds.), The South Atlantic: Present and Past Circulation. Springer-Verlag, Berlin, pp. 13-44.

Sandwell, D.T., Smith, W.H.F., 1997. Marine gravity anomaly from Geosat and ERS-1 satellite altimetry. J. Geophys. Res., B 102, $10039-10054$

Shannon, L.V., Hunter, D., 1988. Antarctic Intermediate Water around South Africa. S. Afr. J. Mar. Sci. 6, 107-117.

Shipboard Scientific Party, 1999a. Site 1088. In: Gersonde, R., Hodell, D.A., Blum, P., et al. (Eds.), Proc. ODP, Init. Repts., vol. 177. Available from: Ocean Drilling Program. Texas A\&M University, College Station, TX 77845-9547, USA, pp. 1-66 [CD-ROM].

Shipboard Scientific Party, 1999b. Site 1089. In: Gersonde, R., Hodell, D.A., Blum, P., et al. (Eds.), Proc. ODP, Init. Repts., vol. 177. Available from: Ocean Drilling Program. Texas A\&M
University, College Station, TX 77845-9547, USA, pp. 1-97 [CD-ROM].

Shipboard Scientific Party, 1999c. Site 1090. In: Gersonde, R., Hodell, D.A., Blum, P., et al. (Eds.), Proc. ODP, Init. Repts., vol. 177. Available from: Ocean Drilling Program. Texas A\&M University, College Station, TX 77845-9547, USA, pp. 1-101 [CD-ROM].

Stow, D.A.V., Faugères, JC., Viana, A., Gonthier, E., 1998. Fossil contourites: a critical review. Sediment. Geol. 115, 3-31.

Sykes, T.J.S., Ramsay, A.T.S., Kidd, R.B., 1998. Southern hemisphere Miocene bottom-water circulation: a palaeobathymetric analysis. In: Cramp, A., MacLeod, C.J., Lee, S.V., Jones, E.J.W. (Eds.), Geological Evolution of Ocean Basins: Results from the Ocean Drilling Program, Special Publications, vol. 131. Geological Society, London, pp. 43-54, Chap. 10.

Tucholke, B.E., Embley, R.W., 1984. Cenozoic regional erosion of the abyssal sea floor off South Africa. In: Schlee, J.S. (Ed.), Interregional Unconformities and Hydrocarbon Accumulation. AAPG Memoir, vol. 36, pp. 145-164.

Turneau, R., Ledbetter, M.T., 1989. Deep circulation changes in the South Atlantic ocean: response to initiation of northern hemisphere glaciation. Paleoceanography 4, 565-583.

Uenzelmann-Neben, G. (Ed.), 1998. Sedimentation and tectonics of Agulhas Ridge and Agulhas Plateau. Reports on Polar Research, vol. 273. Alfred Wegener Institute for Polar and Marine Research, D-27568 Bremerhaven, Federal Republic of Germany, $22 \mathrm{pp}$.

Venz, K.A., Hodell, D.A., in press. New evidence for changes in Plio-Pleistocene deep water circulation from Southern Ocean ODP Leg 177 Site 1090. Palaeogeography, Palaeoclimatology, Palaeoecology.

Zachos, J.C., Stott, L.D., Lohmann, K.C., 1994. Evolution of early Cenozoic marine temperatures. Paleoceanography 9, 353-387.

Zielinski, U., Gersonde, R., in press. Plio-Pleistocene diatom biostratigraphy from ODP Leg 177, Atlantic sector of the Southern Ocean. Palaeogeography, Palaeoclimatology, Palaeoecology. 